\title{
Electrochemical Destruction of Nitrates and Organics FY1995 Progress Report
}

by

D. T. Hobbs

Westinghouse Savannah River Company

Savannah River Site

Aiken, South Carolina 29808

This paper was prepared in connection with work done under the above contract number with the U.S.

Department of Energy. By acceptance of this paper, the publisher and/or recipient acknowledges the U.S. Government's right to retain a nonexclusive, royalty-free license in and to any copyright covering this paper, along with the right to reproduce and to authorize others to reproduce all or part of the copyrighted paper. 


\section{DISCLAIMER}

This report was prepared as an account of work sponsored by an agency of the United States Government. Neither the United States Government nor any agency thereof, nor any of their employees, makes any warranty, express or implied, or assumes any legal liability or responsibility for the accuracy, completeness, or usefulness of any information, apparatus, product, or process disclosed, or represents that its use would not infringe privately owned rights. Reference herein to any specific commercial product, process, or service by trade name, trademark, manufacturer, or otherwise does not necessarily constitute or imply its endorsement, recommendation, or favoring by the United States Government or any agency thereof. The views and opinions of authors expressed herein do not necessarily state or reflect those of the United States Government or any agency thereof.

This report has been reproduced directly from the best available copy.

Available to DOE and DOE contractors from the Office of Scientific and Technical Information, P.O. Box 62, Oak Ridge, TN 37831; prices available from (615) 576-8401.

Available to the public from the National Technical Information Service, U.S. Department of Commerce, 5285 Port Royal Road, Springfield, VA 22161. 


\section{DISCLAIMER}

Portions of this document may be illegible electronic image products. Images are produced from the best available original document. 
WSRC-TR-95-0248

Keywords: High-Level Waste Nitrite, Caustic, Solution, Cathode, Anode, Acidic, OTD

Retention Time: permanent

\section{Electrochemical Destruction of Nitrates and Organics FY1995 Progress Report (U)}

May 30, 1995

Westinghouse Savannah River Company

P.O. Box 616

Aiken, SC 29802

Prepared for the Department of Energy Office of Technology Development, Office of Environmental Management under Contract DE-AC09-89SR18035 


\title{
Electrochemical Destruction of Nitrates and Organics FY1995 Progress Report (U)
}

\author{
by \\ D.T.THC \\ D. T. Hobbs
}

May 30, 1995

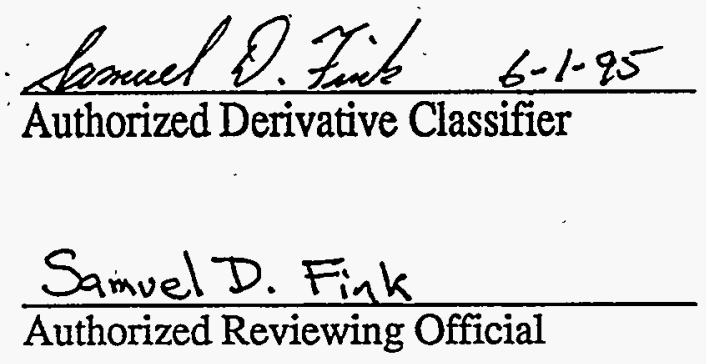

Savannah River Technology Center

Westinghouse Savannah River Company

Aiken, SC 29802

Prepared for the Department of Energy Office of Technology Development, Office of Environmental Management under Contract DE-AC09-89SR18035 


\subsection{SUMMARY}

Progress has been made in the evaluation and development of electrochemical technology for the treatment of radioactive wastes stored within the Department of Energy (DOE) complex. Major accomplishments of this program during FY1995 include the following:

(1) documented bench-scale tests demonstrating the destruction of nitrate and nitrite in radioactive Savannah River Site (SRS) wasste,

(2) developed engineering models for the parallel-plate and porous electrode electrochemical reactors and a dynamic flowsheet model for the treatment of SRS decontaminated salt solution,

(3) documented bench-scale tests demonstrating the destruction of EDTA and other organic compounds in simulated Hanford waste,

(4) completed laboratory tests evaluating fluidizéd-bed and packed-bed technology for the destruction of nitrates and nitrites and the removal of $\mathrm{Hg}(\mathrm{II}), \mathrm{Ru}(\mathrm{II})$, and $\mathrm{Cr}(\mathrm{VI})$ from alkaline waste solutions, and

(5) performed fundamental studies to gain an understanding of the mechanism for the electrochemical reduction of nitrate and nitrite and the oxidation of ethylenediaminetetraacetate anion.

Other significant activities include awarding a contract to the Electrosynthesis Company to conduct a large-scale demonstration of the electrochemical destruction of nitrates and organic compounds in simulated SRS and Hanford wastes and the design and installation . of a pilot-scale electrochemical testing facility.

\subsection{INTRODUCTION}

Production of nuclear materials within the DOE complex has yielded large volumes of high-level waste containing hazardous species such as nitrate, nitrite, chromium, and mercury. Processes being developed for the permanent disposal of these wastes are aimed at separating the bulk of the radioactivity, primarily ${ }^{137} \mathrm{Cs}$ and ${ }^{90} \mathrm{Sr}$, into a small volume for incorporation into a vitrified wasteform, with the remainder being incorporated into a low-level wasteform. Performance assessments of the low-level wasteforms indicate that major contributors to environmental release and personnel exposure risks include nitrate, nitrite, ${ }^{99} \mathrm{Tc}$ and ${ }^{106} \mathrm{Ru}$. Some of the waste contains organic complexants and other organics that are safety concerns from the generation of flammable gases and adversely impact radionuclide separation processes.

Electrochemical treatment is one possible technology for the destruction of nitrates, nitrites, and organic complexants and compounds, as well as the removal of radionuclides and hazardous metals from the waste solutions. In the electrochemical reactor, nitrate and nitrite are reduced to nitrogen-containing gases: nitrous oxide, nitrogen and ammonia. These gases have very low solubility in the alkaline salt solution and are released into the vapor phase, thus separating from the solution. In an undivided cell, the corresponding anode reaction is the oxidation of hydroxide to oxygen and water. The net electrochemical reduction of nitrate or nitrite would then produce one equivalent of hydroxide per nitrate or nitrite reduced. Note that there are no additional chemicals added to the waste as a result of the electrochemical treatment. 
Organic compounds are oxidized at the anode of the electrochemical reactor. The final products for a hydrocarbon compound are carbon dioxide and water. For organic compounds containing other elements, such as nitrogen in ethylenediaminetetracetic acid, nitrogen would also be a product of the organic compound destruction.

Previous work funded by the Office of Technology Development has demonstrated the electrochemical destruction of nitrates and nitrites in bench-scale flow cell reactors with simulated waste solutions [1-4] and in an unstirred batch cell with Savannah River Site (SRS) decontaminated salt solution [5]. Electrochemical destruction of organic compound in nonradioactive Hanford complexant concentrate waste simulants has been demonstrated in testing at PNL funded by the Tank Waste Remediation and Safety program [6]. Work summarized in this progress report covers the period from December, 1993 through May, 1995 with emphasis on FY1995 activities.

\subsection{SUMMARY OF RESULTS}

\subsection{FY1993 and FY1994 Studies}

\subsubsection{Identification of Candidate Waste Streams [7]}

Four candidate waste streams from DOE sites were identified for the evaluation of electrochemical processes for the treatment of high-level wastes (HLW). The waste streams selected included: (1) Hanford Concentrated Neutralized Tank Waste, (2) Tdaho Chemical Processing Plant Sodium-Bearing Waste, (3) Oak Ridge Melton Valley Storage Tank Supernate Waste, and (4) Savannah River Site Decontaminated Salt Solution Waste. All but the Idaho Falls waste are highly alkaline.wastes. In addition to nitrate and nitrite, the wastes contain hazardous metals and organic compounds that impact radionuclide separations processes. Simulant compositions were selected based on published reports and discussions with site representatives.

\subsubsection{Destruction of Nitrates and Nitrites [5]}

A technical report was issued detailing the results of laboratory studies investigating the electrolytic treatment of alkaline solutions carried out under the direction of the Savannah River Technology Center from 1985-1992. Key findings of the studies follow. Electrolytic treatment has been demonstrated at the laboratory scale to be feasible for the destruction of nitrate and nitrite and the removal of radioactive species such as ${ }^{99} \mathrm{Tc}$ and ${ }^{106} \mathrm{Ru}$ from Savannah River Site (SRS) decontaminated salt solution and other alkaline wastes. The reaction rate and current efficiency for the removal of these species were dependent on cell configuration, electrode material, nature of electrode surface, waste composition, current density, and temperature.

Nitrogen, ammonia, and nitrous oxide were identified as the nitrogen-containing reaction products from the electrochemical reduction of nitrate and nitrite under alkaline conditions. Voltammetric studiés indicated a complex reaction mechanism involving surface phenomena and reactions that were not necessarily mass transfer controlled. In an undivided cell, results suggested an electrocatalytic role for oxygen via the generation of the superoxide anion.

In general, more efficient reduction of nitrite and nitrate occurred at cathode materials with higher overpotentials for hydrogen evolution. Nitrate and nitrite destruction was also demonstrated in engineering-scale flow reactors. In flow reactors, the nitrate/nitrite destruction efficiency was increased with an increase in the current density, temperature, and when the cell was operated in a divided cell configuration. $\mathrm{Nafion}^{{ }^{\circledR}}$ ion-exchange 
membranes exhibited good stability and consistent performance as separators in the divided-cell tests. The membranes were also shown to be unaffected by radiation at doses approximating four years of cell operation in treating the SRS decontaminated salt solution.

Tests indicated that the Colli(cyclam) complex is an effective catalyst for the reduction of nitrate and nitrite in strong base, approximately to the same extent as in neutral or nonaqueous solutions. Nearly complete reduction of nitrate and nitrite to mixtures of hydroxylamine and ammonia took place with reasonable current efficiencies at a variety of electrode materials.

\subsubsection{Destruction of Organic Compounds [8]}

Bench-scale tests were initiated in FY1994 and completed in FY1995 to determine the effects of key operating parameters on the destruction of organic compounds known to be present.in Hanford HLW. Parameters under evaluation included cathode materials, cell configuration, chloride and solids concentration, organic species, current density, flowrate, and temperature. All testing used the nonradioactive SY-SIM-93A simulant for the Hanford Complexant Concentrate Tank Waste, containing $5300 \mathrm{ppm}$ total organic carbon.

Results reported in FY1994 indicated that the cathode material influences the rate of organic and nitrate/nitrite destruction. The use of platinized titanium, nickel, and stainless steel showed higher organic destruction rates than lead oxide. Lead oxide exhibited the best nitrate/nitrite destruction performance. Nickel offered the best tradeoff in destruction rates for simultaneous organic and nitrate/nitrite destruction.

The presence of chloride $(0.27 \mathrm{wt} \%)$ was observed to increase the rate of organics destruction. The enhanced rate of destruction was attributed to the indirect oxidation through a chloride/hypochlorite redox couple. Even in the absence of chloride, the electrochemical process was determined to be capable of achieving the treatment objective of organic compound destruction to a concentration of $\leq 1556 \mathrm{ppm}$ total organic carbon (TOC).

Experimental results also indicated that the presence of insoluble solids (1-3 wt \%) showed essentially no effect on the rate of organics destruction. In addition to ethylenediaminetetraacetate (EDTA), the rate of destruction of other organic compounds was also studied. Compounds investigated included: formate, oxalate, acetate, citrate, and N-(2-hydroxyethyl)ethylenediaminetriacetate (HEDTA). Formate was observed to have the highest destruction rate. Citrate and acetate were observed to be the most. refractory.

\subsubsection{Development of Engineering Models}

\subsubsection{Parallel-Plate Electrochemical Reactor [9]}

A rigorous parallel-plate electrochemical reactor model was developed that simulated the destruction of nitrates and nitrites in alkaline solutions. In the model, an alkaline solution containing nitrate and nitrite flow into the reactor and electrochemical destruction of the nitrate and nitrite occurs at the cathode. In the divided cell model, a sodium hydroxide solution is fed into the anolyte channel and the nitrate/nitrite solution is fed into the catholyte channel. 
The model is a steady-state model that assumes no homogeneous chemical reactions occur in the reactor. The variable operating parameters of the model include: (1) the applied cell potential, (2) the inlet average fluid velocities, (3) anolyte and catholyte flow channel widths, (4) the separator width, (5) the MacMullin number for the separator, (6) anolyte and catholyte feed solution compositions, and (7) the number of node points between the electrodes. The results from the program include: (1) reactor operating conditions, (2) standard state and reference state reaction potentials, (3) average current density and current efficiency for each species, (4) total current density, (5) the production rate per unit electrode area for each species, (6) average inlet and outlet concentration of each species, (7) moles of gas produced per unit time, (8) a material balance for the system, (9) the conversion per pass for each species, and (10) species and solution potential profiles across the reactor outlet.

\subsubsection{Flowsheet Model [10]}

A flowsheet model for the electrochemical denitration process for treating SRS decontaminated salt solution was developed. In addition to the electrochemical reactor, the flowsheet model also included an evaporator/crystallizer, off-gas treatment, and waste disposal. A less rigorous model of the electrochemical reactor was developed for the flowsheet model. This model, referred to as the boundary-layer model, requires much less computational time, and therefore, is better suited as a module in the flowsheet model. The flowsheet model was developed on the SPEEDUPTM platform which enabled the addition of other unit operations or modules as required for the overall treatment process. Preliminary analysis of the flowsheet model indicated that the most efficient method for the destruction of nitrates and nitrites in SRS decontaminated salt solution is in a divided cell operated in batch mode.

\subsubsection{Evaluation of Alternate Reactor Designs}

\subsubsection{Packed-Bed and Fluidized-Bed Reactors [11]}

Testing at the Texas A\&M University evaluated the utilization of packed-bed and fluidized-bed electrochemical reactors for the destruction of nitrate and nitrite and the removal of hazardous metallic species including $\mathrm{Cr}(\mathrm{VI}), \mathrm{Hg}(\mathrm{II})$, and $\mathrm{Ru}(\mathrm{II})$. Compared to planar electrodes, three-dimensional electrodes provide larger areas for electrochemical reactions and increase the probability of reaction because the electrolyte is forced to flow through the electrode. Reduction potentials were measured for the reduction of nitrate and nitrite, chromate, mercuric hydroxide, and the ruthenium nitrosyl compound, $\mathrm{Na}\left[\mathrm{Ru}(\mathrm{NO})\left(\mathrm{NO}_{2}\right)_{4}(\mathrm{OH})\right]$, at a planar nickel electrode as well as at fluidized-bed and packed-bed electrodes comprised of nickel particles. The concentrations of nitrate, nitrite, and metallic species in the nonradioactive simulants were based on those found in SRS high-level waste.

The rate of reduction of the nitrate, nitrite, and the metals in the packed-bed and fluidized-bed reactors are dependent on the size of the electrode particles. The rate decreases at a packed-bed electrode as the particle size increases due to a decrease in the total effective surface area. At a fluidized-bed electrode, two competing factors determine the reaction rate. As in the case of the packed-bed electrode, the rate decreases as the particle size increases. However, in a fluidized-bed cell, the particles are moving and colliding with each other. The conductivity is dependent on the contact and separation of the particles, and therefore, the current (rate) increases with increasing size. Consequently, a maximum current at a particular particle size is achieved. 
The electrolyte flow rate has only a small effect on the reduction rate at a packed-bed electrode. At a fluidized-bed electrode, the flow rate has a significant effect on the reduction rate. In general, a slower flow rate is favored at a fluidized-bed electrode. Testing also indicated that the reduction of chromate produces chromium(III) hydroxide films at a nickel cathode. The film can decrease the reduction of nitrate and nitrite if the surface coverage is significant.

\subsubsection{Porous Metal Electrode [12]}

A model applying porous metal technology for the reduction of nitrate and nitrite in alkaline solution has been developed. The model allows comparison of the operational requirements for the electrochemical reduction of nitrate and nitrite between a porous metal electrode and a parallel-plate electrode. Results from the model indicated that there are definite advantages in using a porous cathode for the electrochemical reduction. The number of cells required for the process to treat the SRS decontaminated salt solution is about 10 less when a porous cathode is used in place of a plate electrode. The total reactor volume when a porous cathode is used is about one-third of that needed when a plate cathode is used.

\subsection{FY1995 Activities/Studies}

\subsubsection{Electrolytic Denitration in Oak Ridge Melton Valley Storage Tank (MVST) Waste}

A single test was carried out to determine the feasibility of nitrate destruction in a nonradioactive simulant of the Oak Ridge MVST waste. This waste is similar to the SRS decontaminated salt solution, but contains on average, a much lower hydroxide concentration ( 0.24 molar versus 1.33 molar). The test was conducted in a divided flow cell reactor at a current density of $5000 \mathrm{~A} / \mathrm{m}^{2}$. Nitrate destruction was observed at a rate very similar to that observed in tests under the same conditions with SRS radioactive wastes (see Figure 1). Thus, it is concluded that the optimum conditions for the destruction of nitrate in Oak Ridge MVST waste will be the same as those determined for SRS alkaline wastes. 
Figure 1. Comparison of Nitrate Destruction in Oak Ridge Melton Vailey Storage Tank Waste Simulant and SRS Radioactive Waste

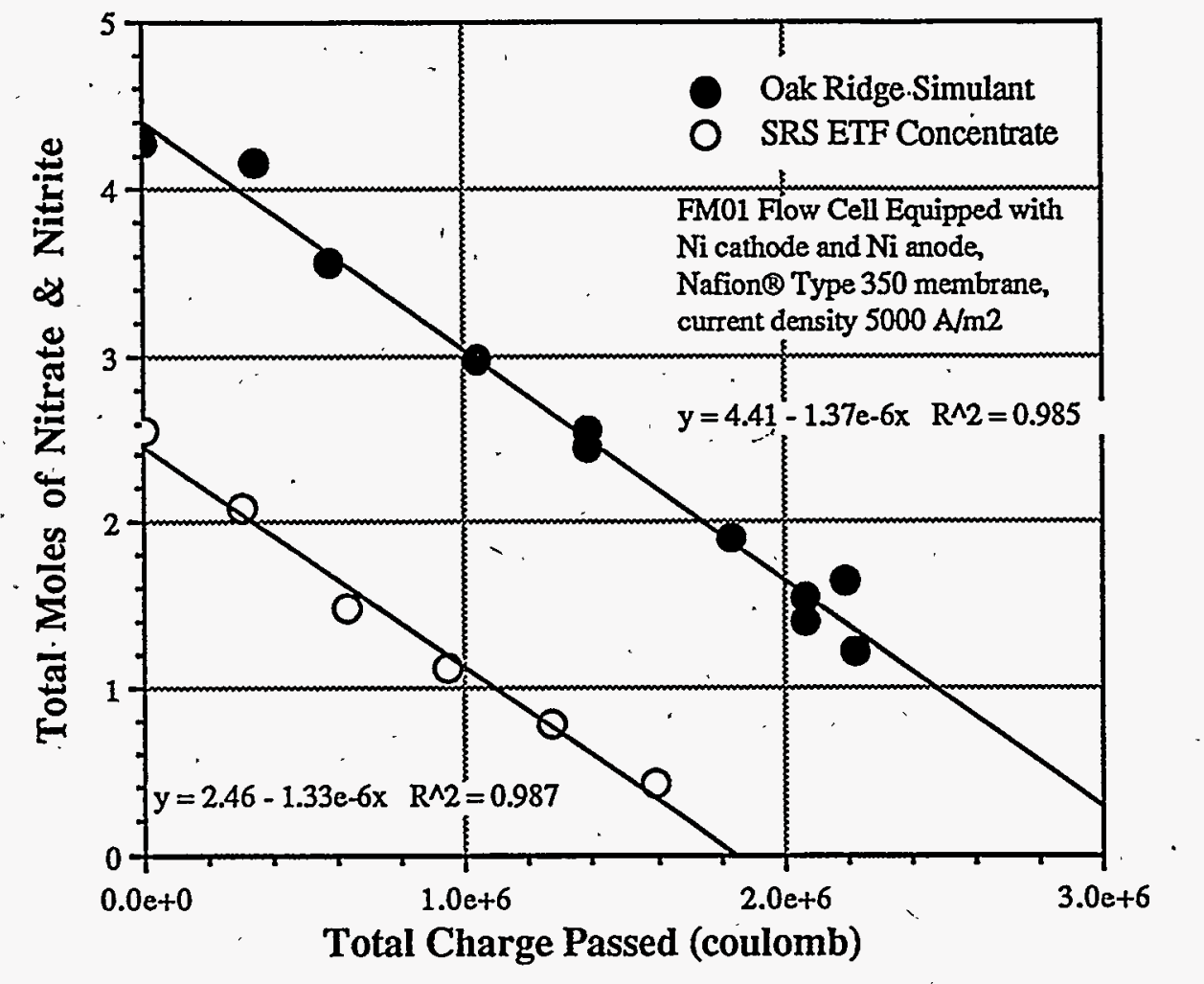

3.2.2. Electrolytic Denitration in the Idaho Chemical Processing Plant (ICPP) SodiumBearing Waste [13]

Proof-of-principle tests demonstrated the destruction of nitrate and the removal of a large number of species in a simulated ICPP Sodium-Bearing waste. No evidence was observed for the evolution of $\mathrm{NO}_{\mathrm{x}}$ in these tests. During electrolysis the $\mathrm{pH}$ of the waste solution increased resulting in the precipitation of ionic species that were not soluble at higher $\mathrm{pH}$ values. It is recommended that additional tests be carried out to determine the limiting current for nitrate destruction, to perform a more accurate mass balance, to determine off-gas products, and to demonstrate nitrate destruction in a laboratory-scale flow cell reactor.

Two tests were conducted with the ICPP Sodium-Bearing Waste simulant. In the first test, the highly acidic simulant was electrolyzed directly as-received. In the second test, $50 \mathrm{wt} \%$ sodium hydroxide solution was added to the simulant resulting in a pH of 10.20 prior to electrolysis. In both tests, nitrate was destroyed as evidenced by the decrease in the nitrate concentration. The nitrate destruction rate was similar for both the highly acidic solution and the alkaline slurry. 


\subsubsection{Electrolytic Denitration in a Radioactive SRS Waste [14]}

A total of 13 tests were carried out with a radioactive waste produced in the Effluent Treatment Facility (ETF). This waste stream is similar in composition to the decontaminated salt solution that will be produced in the In-Tank Precipitation process. Seven of the tests were carried out in a divided cell and six of the tests were carried out in an undivided cell. In the divided cell tests, Nafion ${ }^{\circledR}$ Type 350 ion-exchange membrane was used as the separator between the cathode and anode. Cathode materials tested included nickel, Type 316 stainless steel, and lead. Anode materials tested included nickel and platinized-titanium. Current densities ranged from 0.25 to $0.5 \cdot \mathrm{A} / \mathrm{cm}^{2}$.

Greater than $99 \%$ of the nitrate was destroyed in either an undivided or a divided flow cell reactor. The rate of destruction and the overall power consumption was dependent on the cell configuration and electrode materials. The fastest rate was observed using an undivided cell equipped with a nickel cathode and nickel anode. The use of platinized titanium anode increased the energy requirement and costs compared to a nickel anode in . both the undivided and divided cell configurations.

The energy requirements (electricity costs) for treating the ETF concentrate ranged from 1.8 to 7.6 kilowatt-hour $/ \mathrm{L}(\$ 0.09-0.38 / \mathrm{L})$ based on the experimental results and assuming an electricity cost of $\$ 0.05$ per kilowatt-hour. The largest variation existed for the undivided cell configuration due to a combination of the variation in the destruction rates and the cell potentials. The variation for the divided cell configuration was about $24 \%$ largely due to the difference in the cell potential between the nickel and platinized titanium anodes. The use of platinized titanium in either the undivided or divided cell configurations increased the energy and costs required to achieve nitrate destruction.

\subsubsection{Evaluation of Alternate Reactor Designs}

\subsubsection{Fluidized-Bed and Packed-Bed Reactors [15]}

Work conducted during FY1995 included: (1) evaluation of metallic and non-metallic materials, (2) determination of the effects of temperature; particle size, bed depth, and flowrate on the electrolytic deposition of $\mathrm{Hg}(\mathrm{II}), \mathrm{Ru}(\mathrm{II})$, and $\mathrm{Cr}(\mathrm{VI})$ from alkaline solutions, (3) fundamental studies on the mechanism of electrochemical reduction of nitrate, and (4) preconceptual design of a packed-bed electrochemical process to treat supernate waste. In general, metallic electrodes were found to perform better than nonmetallic electrodes for the reduction of nitrates and electrodeposition of metals. The distribution of nitrate reduction products is dependent on the cathode material. For example, higher amounts of ammonia are produced with a nickel cathode than a lead cathode.

Two concurrent reaction paths have been reported for the electrochemical reduction of nitrate and nitrite. In path 1 (assimilatory), nitrate is reduced to nitrite, which is then reduced to hydroxylamine, and then to ammonia. In path 2 (dissimilatory), nitrate is reduced to nitrite, which is then reduced to nitrous oxide, and then to molecular nitrogen. The yield of ammonia also increases with temperature over the range of 15 to $76^{\circ} \mathrm{C}$.

Reduction of chromate at a nickel cathode produces a chromium(III) hydroxide film that can interfere with the reduction of nitrate and nitrite, but not the reduction of water (hydrogen production). At lead, chromate is reduced primarily to $\mathrm{CrO}_{2}^{-}$, which is soluble, and does not produce a film on the cathode that interferes with the reduction of nitrate and nitrite. Cell operating parameters were identified for the separation of $\mathrm{Hg}(\mathrm{II})$, 
$\mathrm{Ru}(\mathrm{II})$ nitrósyl, and $\mathrm{Cr}(\mathrm{VI})$ species from alkaline waste solutions. Calculations indicate that the concentrations of these metals can be reduced by up to a factor of 100 depending on the particle size, bed depth, and flowrate in a fluidized-bed or packed-bed cell.

\subsubsection{Porous Electrode Reactor [15]}

Two experimental electrochemical cells were constructed during FY1995 to evaluate porous metal electrode technology: (1) a small glass cell having the capability of evaluating a number of porous metal electrodes and (2) an Electrocell MP flow reactor with a flow-through porous nickel cathode. The glass cell was utilized to determine the kinetic parameters for oxygen and hydrogen evolution for four different electrode materials: (1) nickel gauge, (2) nickel foam, (3) TySAR

(4) TySAR ${ }^{\mathrm{TM}} \mathrm{EP}$. The TySAR ${ }^{\mathrm{TM}}$ materials are titanium fibers that are metallurgically bonded to achieve a porous structure that is suitable for flow-by or flow-through operation. The TySARTM EP material contains an electroless metallic coating of platinum. A statistically designed set of tests are being conducted with the MP reactor to measure reaction rates and products over a wide range of simulant concentrations, cell currents, and flowrates. The results of this testing will be reported at the end of FY1995.

\subsubsection{Gas-Diffusion Anode Reactor [15]}

In the parallel-plate electrochemical reactor technology developed to date for the destruction of nitrates and nitrites, the oxidation of hydroxide to produce oxygen and water is the predominant anodic reaction. At standard state conditions, the oxidation of hydroxide occurs at a potential of 0.401 volts higher than that of hydrogen. Thus, significant energy savings could be realized if the oxidation of hydrogen rather than hydroxide was the anodic reaction in the electrochemical cell.

Gas-diffusion anodes that efficiently oxidize hydrogen to protons have been developed for fuel-cell applications. During FY1995, two commercially available gas-diffusion anodes were evaluated: (1) Alupower nickel screen and (2) E-Tek Anti-Percolation anode. The Alupower anode was operated in a caustic anolyte, whereas the E-Tek anode was operated in an acidic anolyte. Both anodes were successfully operated at significantly lower potentials than that for an planar oxygen generating anode. The voltage drop in a membrane cell equipped with a gas-diffusion anode was measured to be as high ás 1.8 volts versus a planar anode at a current density of $0.25 \mathrm{~A} / \mathrm{cm}^{2}$. One problem that was encountered was flooding of the anode. Flooding of the Alupower anode occurred after 10 hours of operation. The E-Tek anode was operated for over 26 hours without flooding.

Additional testing demonstrated the feasibility of processing two different waste streams in a divided cell with the E-Tek anode. The proposed process utilizes a membrane cell equipped with a cation exchange membrane such as the Nafion ${ }^{\mathrm{TM}}$ membranes. The catholyte stream is the alkaline nitrate and nitrite waste solution. Nitrate and nitrite are reduced at the cathode producing nitrogen, ammonia, nitrous oxide, and hydroxide. The anolyte stream is an acidic sodium-sulfate waste solution. Hydrogen is fed to the gasdiffusion anode and oxidized to proton. Sodium ion in the anolyte is transported across the membrane into the catholyte producing sodium hydroxide. Thus, the anolyte is converted into sulfuric acid. The sodium hydroxide and sulfuric acid streams could then be recovered and recycled. Protons will also migrate across the Nafion ${ }^{\mathrm{TM}}$ membrane into the catholyte, which neutralizes a portion of the hydroxide. Results indicated that as long as the ratio of the proton and sodium concentrations is less than 2 , the caustic concentration in the catholyte increases. 


\subsubsection{Electrochemical Destruction of Organic Compounds [15, 16]}

Testing at PNL on the electrochemical destruction of organic compounds present in Hanford tank waste was completed and the results documented in FY1995 (see section 3.1.3 for FY1994 results). The objective of this work was to conduct an engineering evaluation of the electrochemical destruction of organics to provide data on destruction rates, process current efficiencies, process operating conditions, and material performance in support of preconceptual design development. Testing evaluated different cathode materials, cell configurations, different organic compounds, and the effects of varying operating parameters such as current density, temperature, and flowrate.

In an undivided cell configuration, the rate of organic destruction is dependent on the concentration of nitrite. The oxidation of nitrite and organic compounds compete at the anode, which results in a lower rate of organic compound destruction when nitrite is present. For EDTA, the total organic carbon (TOC) destruction rate was approximately $40 \%$ of the maximum rate observed when nitrite was available for oxidation. This behavior is consistent with data for TOC destruction rates for different cathode materials. Lower organic destruction rates are observed at cathodes that exhibit higher nitrate . reduction rates.

Tests indicate that enhanced organic and nitrate destruction rates were achieved by using a divided electrochemical cell. In a divided cell, the anode and cathode are separated by a porous separator. This prevents the reduced or oxidized species from migrating to the other electrode and being oxidized or reduced to the initial oxidation state. Thus, if total nitrogen reduction is desired in conjunction with organic compound destruction, it is advantageous to reduce the total nitrogen concentration before oxidation of the organic compounds.

A factorial design set of experiments was conducted to evaluate the effects of current density, temperature, and flowrate on the destruction of EDTA. Higher current densities resulted in higher TOC destruction rates. Temperature and flow rate also affected the TOC destruction rate, but to a much smaller extent. The destruction rate was slightly higher at lower temperatures and at low to intermediate flow rates. .

Fundamental studies were also carried out during FY1995 to gain a better understanding of the reaction mechanism for the electrochemical oxidation of EDTA. Based on these studies, the following sequential reaction scheme was proposed for the oxidation of EDTA. 


$$
\begin{aligned}
\mathrm{Na}_{4} \mathrm{EDTA}+\mathrm{H}_{2} \mathrm{O} & =\mathrm{ED} 3 \mathrm{~A}+\mathrm{Na}^{+}+\mathrm{H}^{+}+\mathrm{HCHO}+\mathrm{CO}_{2}+2 \mathrm{e}^{-} \\
\mathrm{ED} 3 \mathrm{H}+\mathrm{H}_{2} \mathrm{O} & =\mathrm{S}-\mathrm{EDDA}+\mathrm{Na}^{+}+\mathrm{H}^{+}+\mathrm{HCHO}+\mathrm{CO}_{2}+2 \mathrm{e}^{-} \\
\mathrm{S}-\mathrm{EDDA}+\mathrm{H}_{2} \mathrm{O} & =\mathrm{EDMA}+\mathrm{Na}^{+}+\mathrm{H}^{+}+\mathrm{HCHO}+\mathrm{CO}_{2}+2 \mathrm{e}^{-} \\
\mathrm{EDMA}+\mathrm{H}_{2} \mathrm{O} & =\mathrm{EDA}+\mathrm{Na}^{+}+\mathrm{H}^{+}+\mathrm{HCHO}+\mathrm{CO}_{2}+2 \mathrm{e}^{-} \\
\mathrm{EDA}+2 \mathrm{H}_{2} \mathrm{O}=\mathrm{N}_{2} & +8 \mathrm{H}^{+}+2 \mathrm{HCHO}+\mathrm{CO}_{2}+8 \mathrm{e}^{-} \\
2 \mathrm{HCHO}+6 \mathrm{H}_{2} \mathrm{O}= & 24 \mathrm{H}^{+}+\quad 6 \mathrm{CO}_{2}+24 \mathrm{e}^{-}
\end{aligned}
$$

$\mathrm{Na}_{4} \mathrm{EDTA}+12 \mathrm{H}_{2} \mathrm{O}=\mathrm{N}_{2}+4 \mathrm{Na}^{+}+36 \mathrm{H}^{+}+\mathrm{CO}_{2}+40 \mathrm{e}^{-}$

where, ED3A is ethylenediaminetrinitriloacetate

S-EDDA is $N, N^{\prime}$-ethylendiglycine

EDMA is $\mathrm{N}$-(2-aminoethyl)glycine

EDA is ethylenediamine

$\mathrm{HCHO}$ is formaldehyde

Formaldehyde has been detected in solution. The concentration of formaldehyde increases until all of the EDTA has reacted, and then decreases with further charge being passed. When all of the EDTA has reacted, the TOC concentration has decreased by about $50 \%$.

As was observed in the testing with simulated Hanford waste, the rate of EDTA destruction increases slightly with decreasing temperature over the range from 15 to $80^{\circ} \mathrm{C}$. The reaction order of EDTA was determined to be 0.54 . The fractional reaction order suggests that adsorption of EDTA on the anode surface is an important step in the electron transfer reaction. Based the fractional reaction order and other results from cyclic voltammetry and rotating disc experiments, the following mechanism for the electron transfer has been proposed:

$$
\begin{aligned}
& \mathrm{R}-\mathrm{CH}_{2}-\mathrm{COO}^{-} \stackrel{\mathrm{k1}}{\longrightarrow} \mathrm{R}-\mathrm{CH}_{2}-\mathrm{COO}^{-} \text {(ads) } \\
& \mathrm{R}-\mathrm{CH}_{2}-\mathrm{COO}^{-} \text {(ads) } \stackrel{\mathrm{k} 2}{\longrightarrow} \cdot \mathrm{R}-\mathrm{CH}_{2} \cdot(\mathrm{ads})+\mathrm{CO}_{2}+\mathrm{e}^{-} \\
& \mathrm{R}-\mathrm{CH}_{2} \cdot(\mathrm{ads})+\mathrm{OH}^{-} \underset{\mathrm{k}-3}{\stackrel{\mathrm{k}_{3}}{\rightleftharpoons}} \mathrm{R}-\mathrm{CH}_{2} \mathrm{OH}+\mathrm{e}^{-} \\
& \mathrm{R}-\mathrm{CH}_{2} \mathrm{OH} \underset{-4}{\stackrel{\mathrm{kH}}{\rightleftharpoons}} \mathrm{R}-\mathrm{H}+\mathrm{HCHO}
\end{aligned}
$$

\subsubsection{Development of Engineering Models}

\subsubsection{Parallel-Plate Electrochemical Reactor [15]}

The major objective of work conducted during FY1995 was to validate the boundarylayer parallel-plate reactor model for the destruction of nitrate and nitrite in alkaline waste solutions. Results indicated excellent agreement between the predicted and experimentally determined solution concentrations and cell voltages. The excellent agreement extended to both the Electrocell MP and the ICI FM01-LC reactors and for both simulated and radioactive wastes, showing the generality of the model as a $m$. predictive tool. 
Sodium transport across the Nafion ${ }^{\mathrm{TM}}$ membrane in a divided electrochemical cell has . been measured as a function of temperature and current density. Testing is underway to measure off-gas compositions as a function of charge passed and cathode material (i.e., nickel, stainless steel, and lead) so that a complete nitrogen mass balance can be made and exchange current densities for the production of nitrogen, nitrous oxide, and ammonia be determined. To date, the exchange current densities have been determined for a nickel cathode.

\subsubsection{Flowsheet Model [17]}

During FY1995, a strategy was developed for optimizing the operation of the batch electrochemical reactor. The strategy was to set the current density of the cell to the highest possible value that minimizes hydrogen production. After determination of the exchange current densities, a further refinement may be added to include minimization of ammonia production.

Several steady-state optimization runs were performed úsing this methodology. The: results indicate that at high nitrate and nitrite concentrations, the cell can be operated at very high current densities (up to $1.4 \mathrm{~A} / \mathrm{cm}^{2}$ ) without significant amounts of hydrogen being produced. As the total nitrate and nitrite concentration decreases during a batch run, so does the optimal current density. Tests are planned to validate this control strategy in bench-scale experiments.

3.2.7 Large-Scale Demonstration of Electrolytic Destruction of Nitrates and Organic Compounds in Nonradioactive Waste Simulants.

Testing services were competitively bid for a large-scale demonstration of the destruction of nitrates and organics in nonradioactive simulants of Hanford and SRS wastes. Three companies submitted proposals and the contract was awarded in March, 1995 to the Electrosynthesis Company (ESC) of Lancaster, New York. ESC will use a commercialscale flow reactor manufactured by the ICI of Great Britain. The demonstration will consist of four tests in which the reactor will be operated for a minimum of 40 hours or until at least $50 \%$ of the nitrate/nitrite and the TOC has been destroyed. The electrode potentials, the charge passed, the liquid and gas flowrates, the temperature of the liquid streams, and the composition of the liquid and gas streams will be monitored throughout each tests.

\subsubsection{Pilot-Scale Testing Facility [18]}

After considering three options, the Experimental Thermal Fluids laboratory at SRTC was selected as the site for a pilot-scale testing facility. The testing facility will consist of an electrochemical reactor and the necessary feed tanks, pumps, and gas/liquid separation equipment to operate continuously for up to 1000 hours. Liquid and gas flowrates, liquid temperatures, cell potentials and currents will be monitored continuously and recorded in the data acquisition and control. Gas and liquid samples will be taken and the compositions determined by at-line and off-line analytical methods. The testing facility will have the capability of isothermal operation over the range from 25 to $80^{\circ} \mathrm{C}$. Installation and operationally checkout is scheduled to be completed by the end of FY1995. 


\subsection{PRESENTATIONS AND PUBLICATIONS}

Following is a list of recent presentations, journal publications, and papers submitted for publication reporting the work associated with the evalution and development of electrochemical technology for the destruction of nitrates, nitrites, and organic compounds and the removal of metals and radionuclides in waste solutions.

D. T. Hobbs, J. D. Genders, and D. Hartsough, "Electrochemical Treatment of Liquid Nuclear Wastes," presented at 185th Meeting of the Electrochemical Society," San Francisco, CA, May; 1994.

D. A. Wingard, J. W. Weidner, J. W. Van Zee, and D. T. Hobbs, "A Simple Model of the Batch Electrochemical Reduction of $\mathrm{NO}_{3}{ }^{-} / \mathrm{NO}_{2}{ }^{-1}$ presented at 185 th Meeting of the Electrochemical Society," San Francisco, CA, May, 1994.

D. H. Coleman, R. E. White, and D. T. Hobbs, "A Parallel Plate Electrochemical Reactor (PPER) for the Destruction of Nitrates and Nitrites in Alkaline Waste Solutions," presented at and published in the proceedings of the 185th Meeting of the Electrochemical Society," San Francisco, CA, May, 1994.

D. T. Hobbs, "Electrochemical Treatment of Alkaline Nuclear Wastes," presented at the 208th Meeting of the American Chemical Society, Washington, DC, August 24, 1994.

D. T. Hobbs, "Electrochemical Treatment of Alkaline Nuclear Wastes," presented at the 8th International Forum on Electrolysis in the Chemical Industry, Lake Buena Vista, FL, November 17, 1994.

D. H. Coleman, R. E. White, and D. T. Hobbs, "A Parallel Plate Electrochemical Réactor -(PPER) for the Destruction of Nitrates and Nitrites in Alkaline Waste Solutions," J.' Electrochem. Soc., 1995, 142(4), 1152.

S. N. R. Pakalapati, B. N. Popov, R. E. White, and D. T. Hobbs, "Anodic Oxidation of Tetrasodium Ethylenediaminetetraacetic Acid in Alkaline Solutions (U)," presented at the 187th Meeting of the Electrochemical Society, Reno, NV, May, 1995.

J. David Gender, Dan Hartsough, and David T. Hobbs, "Electrochemical Reduction of . Nitrates and Nitrites in Alkaline Nuclear Waste Solutions," J. Appl. Electrochem. accepted for publication.

Shilesh Prasd, John W. Weidner, and Andrew E. Farell, "A Boundary Layer Parallel Plate Electrochemical Reactor Model for the Destruction of Nitrates and Nitrites in Alkaline Waste Solutions," submitted for publication.

E. E. Kalu, R. E. White, and D. T. Hobbs, "A Performance Criteria for a Membrane Cell Batch Reactor with Consecutive Reactions," submitted for publication.

E. E. Kalu, R. E. White, and D. T. Hobbs, "Hydrogen Anode for Nitrate Destruction," submitted for publication. 


\subsection{ACKNOWLEDGEMENTS}

This work was funded by the Office of Technology Development, Office of

Environmental Management through the Efficient Separations and Processing Program, Teresa B. Fryberger, Headquarters Program Manager, and Allison M. Blackmon, cognizant Technical Program Officer.

\subsection{REFERENCES}

1. J. D. Genders, "Final Report -Electrochemical Processing Of Nitrate Waste Solutions (U)," May 31, 1990 (WSRC-TR-90-491).

2. J. D. Genders, N. Weinberg, and D. Hartsough, "Phase II Final Report Electrochemical Processing Of Nitrate Waste Solutions, (U)" October 7, 1992 (WSRC-TR-93-090).

3. D. T. Hobbs, "Electrochemical Treatment of Nuclear Waste at the Savannah River Site," Chapter 12 in Electrochemistry For A Cleaner Environment, edited by J. D. Genders and N. L. Weinberg, Electrosynthesis Company, Inc., East Amherst, New York, 1992.

4. D. T. Hobbs, "Electrochemical Treatment of Alkaline Nuclear Wastes," presented at the 208th Meeting of the American Chemical Society, Washington, DC, August 24, 1994.

5. D. T. Hobbs, "Summary Technical Report on the Electrochemical Treatment of Alkaline Nuclear Wastes (U)," WSRC-TR-94-0287, July 30, 1994.

6. W. E. Lawrence, J. E. Surma, M. F. Buehler, and G. Pillay, "Electrochemical Treatment of Organic Tank Wastes," presented at the 185th Meeting of the Electrochemical Society, San Francisco, CA, May 23, 1994.

7. D. T. Hobbs, "Composition of Simulants Used in the Evaluation of Electrochemical Processes for the Treatment of High-Level Wastes (U)," WSRC-TR-94-0286, June 27, 1994.

8. W. E. Lawrence, J. E. Surma, M. F. Buehler, J. H. Sukamto, G. Pillay, K. L. Gervais, K. N. Sasser, and M. D. Ryder "Interim Report on the Electrochemical Organic/Complexant Destruction in Hanford Tank Waste Simulants (U)," WSRC-RP-94-756, July 28, 1994.

9. D. H. Coleman and R. E. White, "Summary Report of the Parallel-Plate Electrochemical Model (U)," WSRC-RP-93-1577, Decembèr 15, 1993.

10. S. Prasad, A. E. Farell, J. W. Weidner, and R. E. White, "-Interim Report on the Flowsheet Model for the Electrochemical Treatment of Liquid Radioactive Wastes (U)," WSRC-RP-94-1149, August 31, 1994.

11. J. O'M. Bockris and J. Kim, "Interim Report on the Evaluation of Packed-Bed and Fluidized-Bed Electrodes," WSRC-RP-94-835, August 15, 1994. 
12. K. Jha, J. W. Weidner, and R. E. White, "Interim Report on the Evaluation of a Porous Cathode Used for the Electrochemical Reduction of Nitrate and Nitrites in Liquid Wastes (U)," WSRC-RP-94-1148, September 30, 1994.

13. D. T. Hobbs, "Electrolytic Treatment of ICPP Sodium-Bearing Waste Simulant," WSRC-RP-94-1300, December, 1994.

14. D. T. Hobbs, "Electrolytic Denitration of Radioactive Savannah River Site Waste (U)," WSRC-TR-95-0176, April 26, 1995.

15. SCUREF Monthly Status Reports, Task Order \#112, October, 1995 through May, 1995.

16. W. E. Lawrence, J. E. Surma, M. F. Buehler, J. H. Sukamto, G. Pillay, K. L. Gervais, K. N. Sasser, and M. D. Ryder, "Final Report on the Electrochemical Organic/Complexant Destruction in Hanford Tank Waste Simulants (U)," WSRC-RP-95-111, January 16, 1995.

17. S. Prasad, A. E. Farell, J. W. Weidner, and R. E. White, "Interim Report Flowsheet Model for the Electrochemical Treatment of Liquid Radioactive Wastes (U)," WSRC-TR-0252, April 11, 1995.

18. D. T. Hobbs, "Test Plan for the Pilot-Scale Evaluation of Electrochemical Destruction Processes (U)," WSRC-RP-95-235, February 9, 1995. 